European Journal of Sustainable Development

Research, 2018, 2(2), 26

ISSN: 2542-4742

\title{
Performance Characteristics Comparison of CNG Port and CNG Direct Injection in Spark Ignition Engine
}

\author{
Rajesh Patel ${ }^{1 *}$, Pragnesh Brahmbhatt ${ }^{2}$ \\ ${ }^{1}$ Pacific Academy of Higher Education and Research, Udaipur, Rajasthan, INDIA \\ ${ }^{2}$ Government Engineering College, Dahod, Gujarat, INDIA
}

*Corresponding Author: rjpatel78@gmail.com

Citation: Patel, R. and Brahmbhatt, P. (2018). Performance Characteristics Comparison of CNG Port and CNG Direct Injection in Spark Ignition Engine. European Journal of Sustainable Development Research, 2(2), 26. https://doi.org/10.20897/ejosdr/82058

Published: March 20, 2018

\begin{abstract}
A comparative performance analysis is being carried out on a four cylinder, four stroke cycle, spark ignition engine having displacement volume $1297 \mathrm{cc}$. The cylinder head of original gasoline based engine was modified by drilling holes from upper surfaces of head to individual combustion chamber to convert the engine in a CNG direct injection engine. The CNG port injection (CNG-PI) system and CNG direct injection (CNG-DI) system were incorporated with the single engine. The engine was retrofitted to run on both CNG-PI and CNG-DI system alternately with common CNG tank and other engine loading and measurement system. The engine was equipped with electrical dynamometer having rheostat type loading. The CNG direct injection system was incorporated with various sensors and engine ECU. The operating parameters can be obtained on computer screen by loading the computer with engine through switch box. The engine was run over the speed range of $1000 \mathrm{rpm}$ to $3000 \mathrm{rpm}$ with incremental speed of $300 \mathrm{rpm}$. The performance parameters were calculated from observations and recorded for both CNG-PI and CNG-DI system. The experimental investigation exhibits that, the average $7-8 \%$ reduction in BSFC while the engine was running with CNG-DI system as compared to that of CNG-PI system. Also the engine produced 8$9 \%$ higher brake torque and hence higher brake power. The engine gives 6-7\% higher brake thermal efficiency with CNG-DI system as compared to CNG-PI system.
\end{abstract}

Keywords: compressed natural gas (CNG), CNG-PI system, CNG-DI system

\section{INTRODUCTION}

The CNG is one of the best alternative fuel due to its cleanest burning characteristics and high octane rating (Liu et al., 2013). Now-a-days, the CNG is used in the stationary as well as transport engine due to its ease availability of conversion technology (Semin, 2008). The use of CNG as a fuel is not limited to small and medium size vehicles, but heavy vehicles are also popular with CNG fuel in the transportation sector (Jahirul et al., 2010). Most of the vehicles operated on CNG fuel are of bi-fuel type in which the vehicle is started with gasoline fuel and then it is converted into CNG mode. This bi-fuel type of vehicle is generally petrol based engine which can run on both type of fuel alternately (Munde Gopal, and Dalu Rajendra, 2012). The performance of bi-fuel engine with port injection system is poor in terms of lower brake power and less volumetric efficiency (Kalam et al., 2009). It is very difficult to develop a high performance compressed natural gas direct injection (CNG-DI) engine for researcher which provides better fuel economy within stringent emission limit. Many researchers have put their extreme effort to develop a new concept of CNG injection system (Kalam and Masjuki, 2011). The volumetric efficiency plays important role in design of CNG injection system as CNG is a compressible fuel because poor 
Table 1. Test Engine Specifications

\begin{tabular}{ll}
\hline Item & Particular \\
\hline Engine Make \& Type: & Maruti Esteem, 4-cylinder, 4-stroke water cooled petrol engine \\
\hline Bore $\times$ Stroke $(\mathrm{mm}):$ & $74 \times 55.5$ \\
\hline Displacement volume $(\mathrm{cc}):$ & 1297 \\
\hline Number of cylinder: & 4 \\
\hline Compression ratio: & 9 \\
\hline Ignition: & Spark ignition \\
\hline Loading: & Electrical dynamometer with rheostat \\
\hline
\end{tabular}

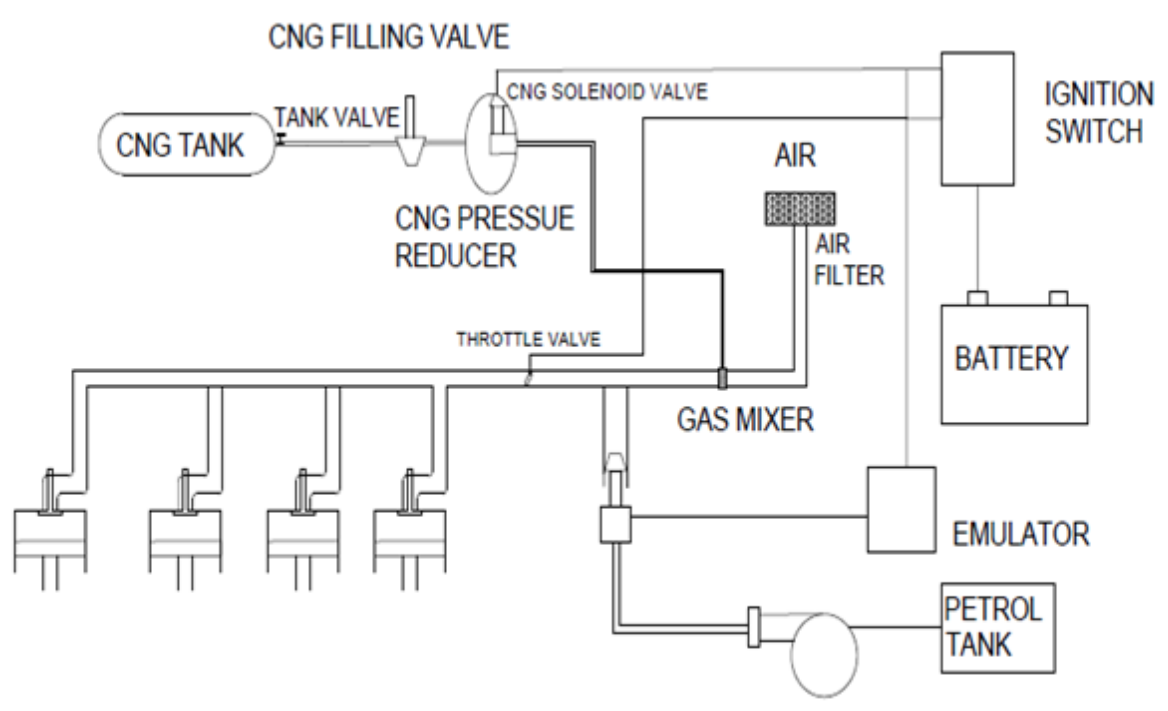

FUEL PUMP

Figure 1. Schematic diagram of CNG port injection system

volumetric efficiency directly results into lower brake power. In SI engine, the fuel supply system can be classified as carburettor system, single or multi point port injection and gasoline direct injection system (Aziz et al., 2010). Similarly, when SI engine is converted into CNG bi-fuel system, the CNG injection system can be categorized as (a) A mixer system which is more sophisticated now and known as single point port injection (CNG-PI), (b) A multi point port injection which is known as sequential injection having each cylinder has one injector and (c) The CNG direct injection (CNG-DI) system in which the CNG is directly injected into the cylinder at the end of compression stroke as in case of diesel engine (Aziz et al., 2010). This new idea of injecting a CNG directly in the cylinder like a diesel injection becomes more popular now-a-days due to its better volumetric efficiency and higher thermal efficiency. Off-course, certain modifications in the engine are required to develop this CNG direct injection system. This research work is carried out to compare the various performance parameters of both CNGPI and CNG-DI system.

\section{SYSTEM AND EXPERIMENTAL PROCEDURE}

The four cylinder SI engine was modified into a CNG direct injection engine. The specifications of the test engine are listed in Table 1.

The cylinder head was modified by drilling 3-mm size hole from upper surface of head and that hole was projected upto the respective combustion chamber throughout. The four holes of 3-mm size were drilled from the upper surfaces of cylinder head to the respective combustion chamber upto the depth of 35-mm. Then, these four holes corresponding to their combustion chambers were subjected to reaming operation for their correct size of 4-mm diameter upto 18-mm depth from the upper surfaces of cylinder head. Further these four holes were tapped for their correct size of 5-mm diameter upto 6-mm depth from the upper surfaces. The edge of brass nipple of 5$\mathrm{mm}$ diameter is inserted into the 6- $\mathrm{mm}$ size hole for individual cylinder and all four cylinders are prepared with this type of connection. The four flexible hoses were projected from all four nipples and other ends of these flexible hoses were connected with four different specially designed gas injectors of injector rail which was located near the throttle body. The injector rail was also connected with ECU through wiring. The gas injector rail was designed for 20-30 bar injection pressure. 


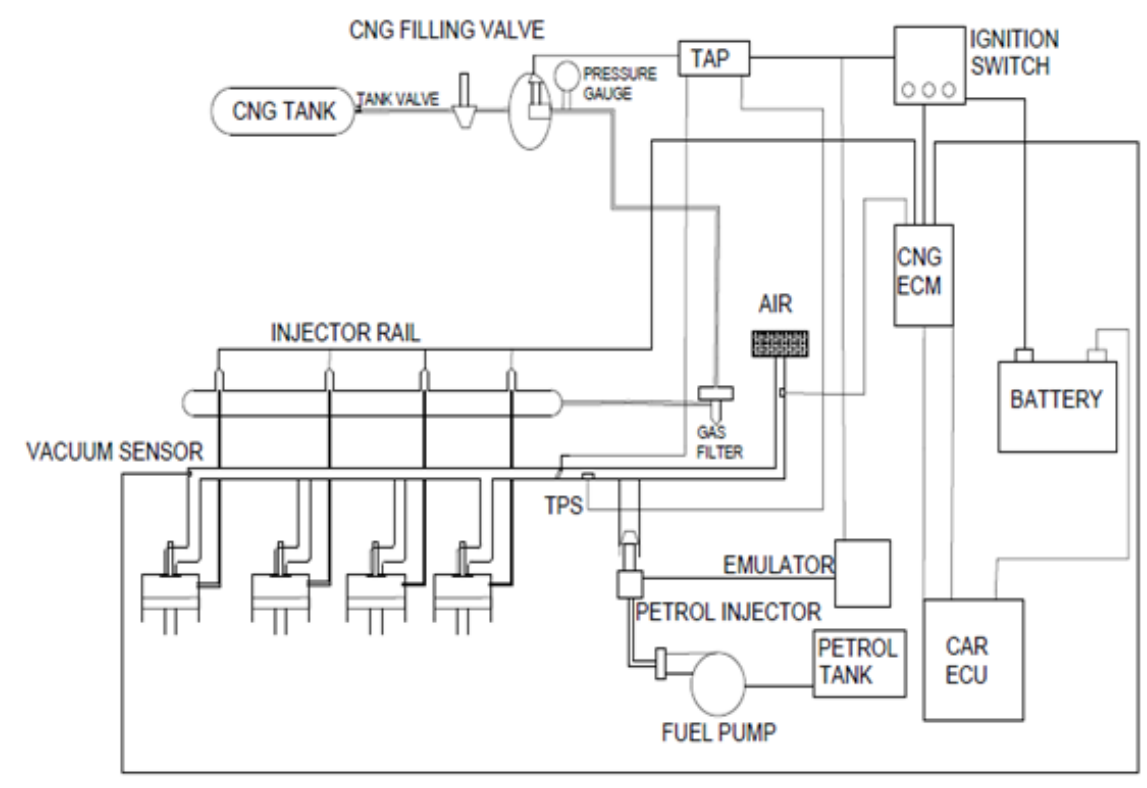

Figure 2. Schematic diagram of CNG direct injection system

The major difficulty in this research work was to get correct value of air pressure at the end of compression stroke. Therefore, before connecting the flexible hoses to their individual gas injector, the open end of hose was connected to the calibrated pressure gauge and engine was sucked manually to check the pressure developed in the cylinder at the end of compression stroke. That pressure was recorded in the range of 15-20 bar and according to that the gas injector rail was set to inject CNG fuel at an injection pressure of 25 bar as per the injection timing $120^{\circ}$ BTDC.

The CNG tank was common for both CNG-PI and CNG-DI system. The CNG-PI system was installed to the engine with its all components like pressure reducer, flow control valve, pressure gauge and flexible hoses. The CNG-DI system was also projected from same CNG tank to gas injector rail via its pressure reducer, control valve, pressure gauge and various sensors at different locations of the engine.

The major difference in the operation of CNG-PI and CNG-DI system is that, in the CNG-PI system, 2-3 bar pressure is sufficient for a single gas injector to inject CNG fuel in the air induction system (throttle body). It is mixed with the air and then the CNG-air mixture is flowing towards the intake system to enter in the cylinder during suction stroke by opening the inlet valve. In the CNG-DI system, only air is inducted during the suction stroke and the $\mathrm{CNG}$ is injected in the cylinder directly at the end of compression stroke with injection pressure of 20-25 bar. The engine was run alternately with CNG-PI and CNG-DI system keeping the operating parameters constant and the observations were recorded.

\section{RESULTS AND DISCUSSIONS}

The air temperature inside the laboratory was about $28^{\circ}-32^{\circ} \mathrm{C}$ during different observations. The CNG-DI system did not have any initial starting problem as the fuel ignited by a spark plug. The engine was generally started with petrol fuel and then that was converted to operate with CNG-PI and CNG-DI system alternately. All the observations were recorded after 2-3 minutes set time required for engine operating on a particular speed and load condition.

\section{Brake Torque}

The engine was run from $1000 \mathrm{rpm}$ to $3000 \mathrm{rpm}$ with each incremental speed of $300 \mathrm{rpm}$. The constant load of $2 \mathrm{~kW}$ was applied to the engine during the observations. It is found that, the brake torque is increased with the speed of engine for CNG-PI system. The brake torque is decreased initially up to $1900 \mathrm{rpm}$ speed and then increased for CNG-DI system as shown in Figure 3. The CNG-PI system produces less brake torque than CNGDI system at same speed and load condition. Because of lack of chemical energy conversion into mechanical energy related to volumetric efficiency, lower brake torque for CNG-DI system from $1000 \mathrm{rpm}$ to $1900 \mathrm{rpm}$ is observed. The variation in cylinder pressure also results into lower brake torque for the CNG-DI system at initial starting condition. In general, the CNG-DI system shows 8 to $9 \%$ higher brake torque than CNG-PI system over the entire speed range. 


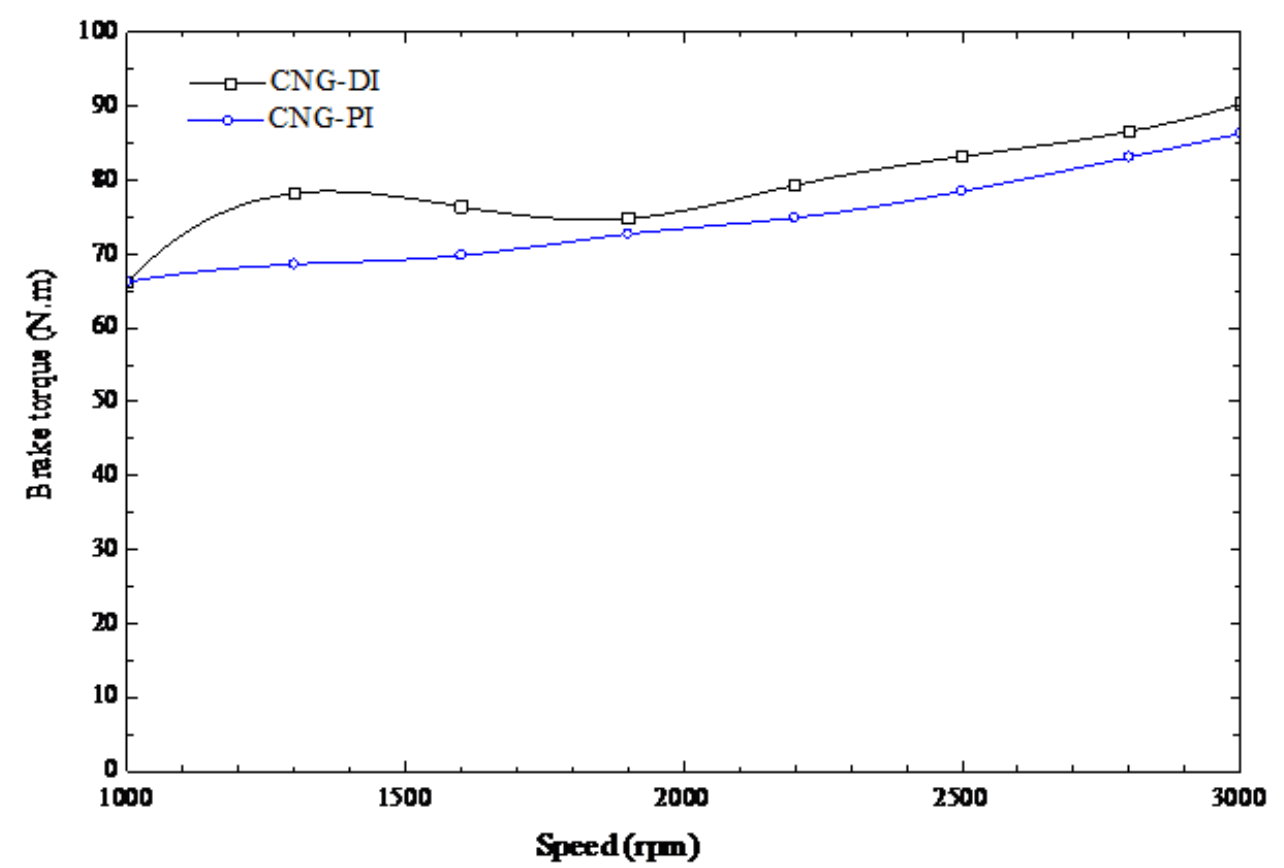

Figure 3. Variation of brake torque with engine speed

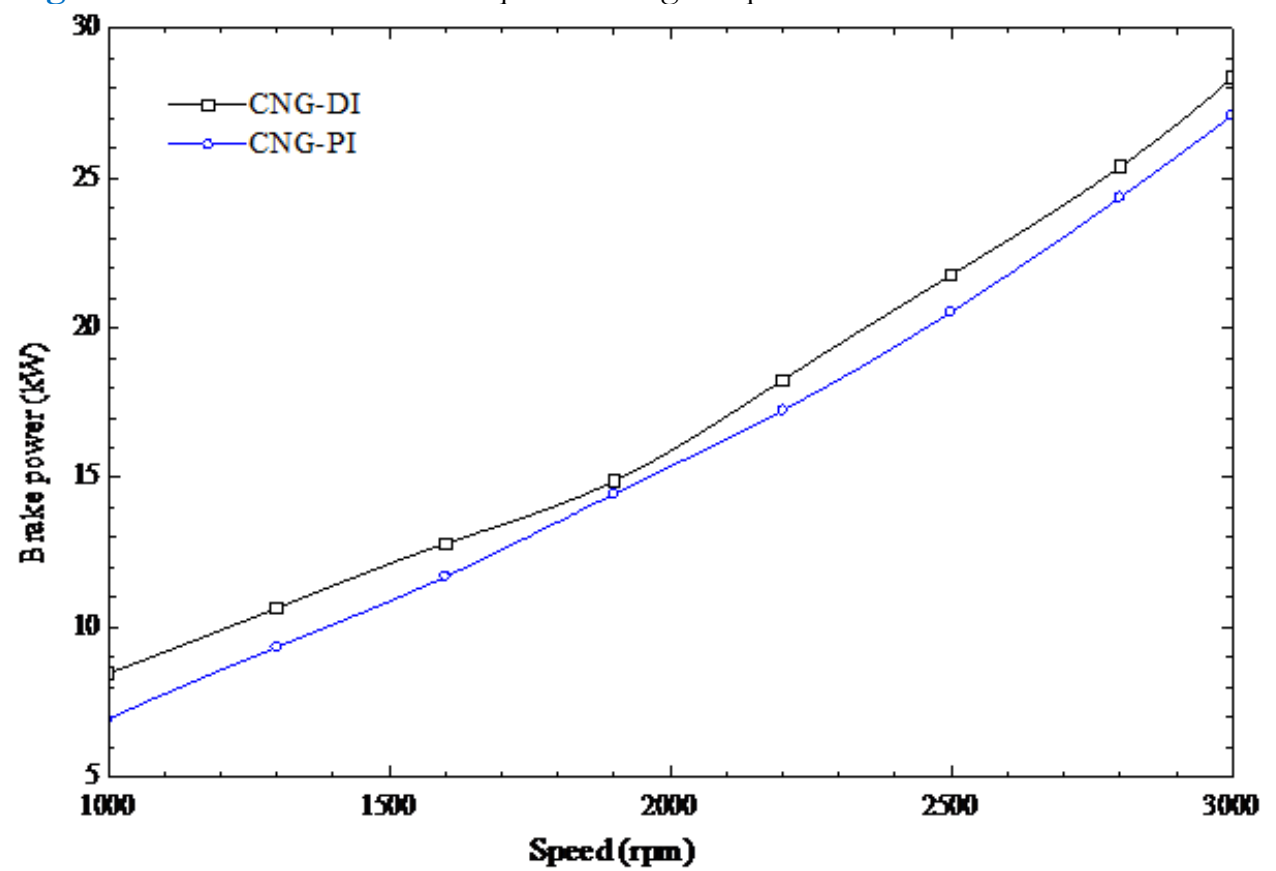

Figure 4. Variation of brake power with engine speed

\section{Brake Power}

Figure 4 predicts the variation of brake power with engine speed for speed range from $1000 \mathrm{rpm}$ to $3000 \mathrm{rpm}$ at constant load of $2 \mathrm{~kW}$. The CNG-DI system produces 4 to $5 \%$ higher brake power at maximum speed of $3000 \mathrm{rpm}$ than that of CNG-PI system which might be due to increasing fuel conversion efficiency. In the speed range from $1000 \mathrm{rpm}$ to $1900 \mathrm{rpm}$, the CNG-DI system produces approximately $12 \%$ higher brake power than CNG-PI system because of higher brake torque corresponding to volumetric efficiency and mixture distribution at a lower operating temperature. Averagely, for over all speed range, the CNG-DI system produces 8 to $9 \%$ higher brake power than CNG-PI system.

\section{Brake Specific Fuel Consumption}

Figure 5 shows the variation of BSFC with engine speed for given speed range. During starting, the BSFC increases up to $1600 \mathrm{rpm}$ for the CNG-PI system due to increase in friction and pumping work. Then the BSFC decreases after $1600 \mathrm{rpm}$ due to rise in fuel efficiency and again after $2200 \mathrm{rpm}$ it started increasing with speed for CNG-PI system due to increasing frictional effect. 


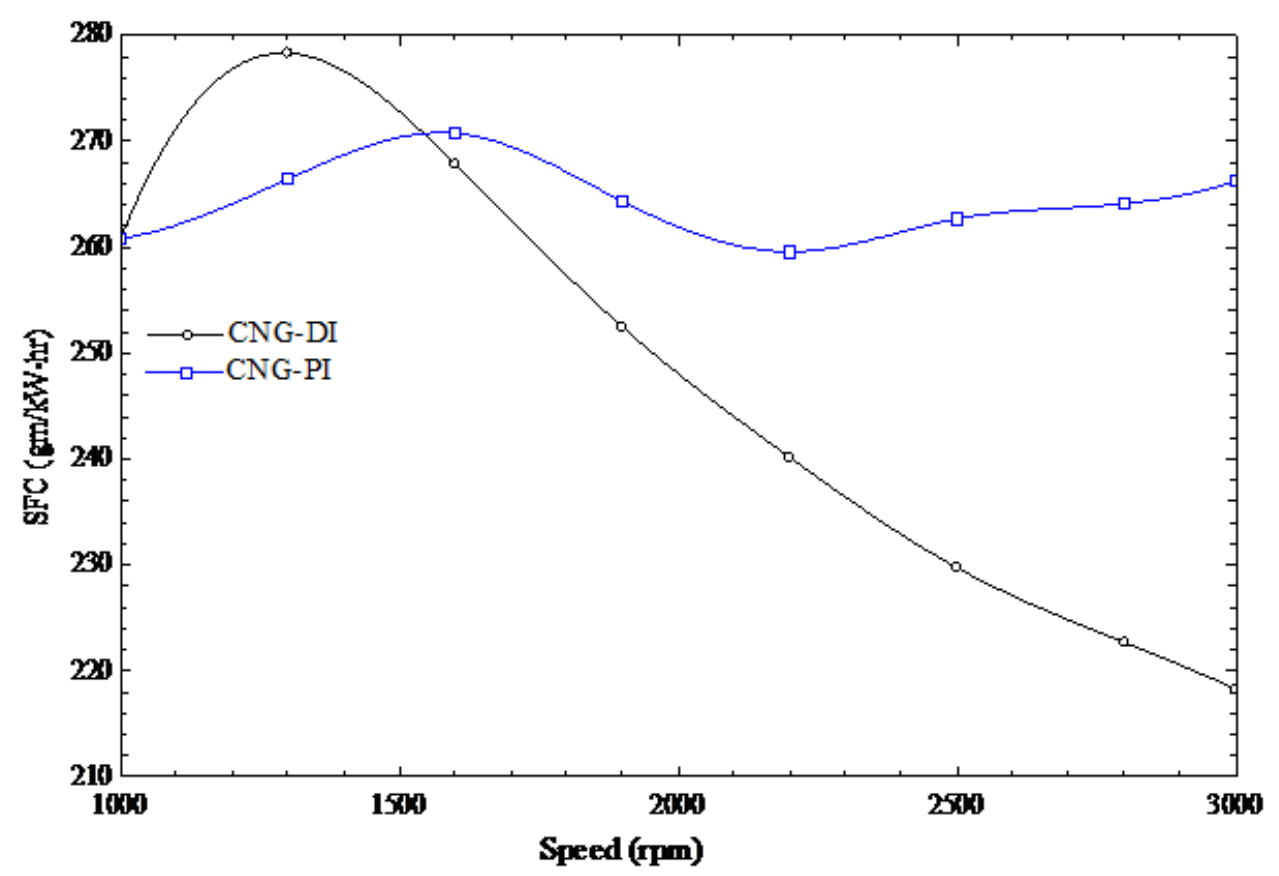

Figure 5. Variation of brake specific fuel consumption with engine speed

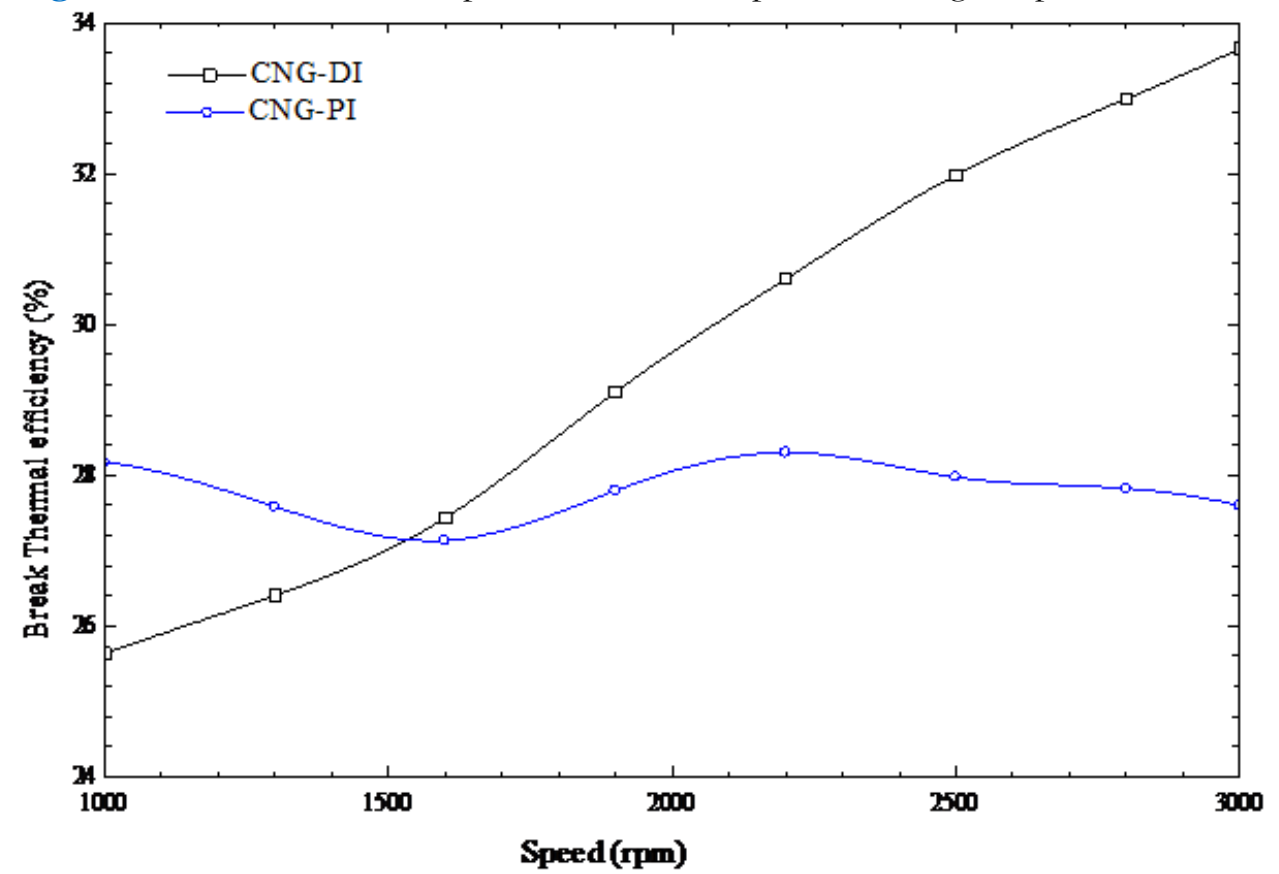

Figure 6. Variation of brake thermal efficiency with engine speed

The BSFC for CNG-DI system is higher than CNG-PI system initially upto $1500 \mathrm{rpm}$ due to less conversion of chemical energy into mechanical energy related to volumetric efficiency. After $1600 \mathrm{rpm}$ speed, the BSFC decreases for CNG-DI system due to increase in volumetric efficiency with increase in speed. Overall, the average BSFC of CNG-DI system is 11 to $12 \%$ lower than that of CNG-PI system in the speed range from 1600 to 3000 rpm.

\section{Brake Thermal Efficiency}

It is the fraction of output power to the input calorific value or heat energy of fuel which is supplied during the same time. It is clear that Figure 6, the brake thermal efficiency for CNG-PI system decreases initially up to 1600 rpm due to less conversion of chemical energy into mechanical energy. Then, it increases from $1900 \mathrm{rpm}$ to 2200 $\mathrm{rpm}$ due to increase in volumetric efficiency. Again it decreases slowly from $2500 \mathrm{rpm}$ to $3000 \mathrm{rpm}$ due to increasing frictional effect.

The brake thermal efficiency for CNG-DI system is lower than CNG-PI system initially upto $1300 \mathrm{rpm}$ speed. Then, it started increasing from $1600 \mathrm{rpm}$ due to more conversion of chemical energy into mechanical work. 
However, the brake thermal efficiency of CNG-DI system is about 10 to $11 \%$ higher than that of CNG-PI system over the speed range from 1600 to $3000 \mathrm{rpm}$.

\section{CONCLUSION}

After the experimental investigation, the given affirmative conclusions are drawn:

i. The base gasoline engine can be converted into CNG-DI system by making modification in the cylinder head and by installing other sophisticated measuring components for CNG injection.

ii. On an average, the CNG-DI system showed 8-9\% higher brake power than the CNG-PI system over the given speed range.

iii. The average BSFC is approximately 7 to $8 \%$ lower in case of CNG-DI system than the CNG-PI system due to higher volumetric efficiency of CNG-DI system.

iv. On average, the brake thermal efficiency is 6 to $7 \%$ higher for the CNG-DI system than the CNG-PI system due to more scope of conversion of heat energy into mechanical work

\section{NOMENCLATURE}

\begin{tabular}{|l|l|}
\hline CNG & Compressed Natural Gas \\
\hline CNG-PI & CNG Port Injection \\
\hline CNG-DI & CNG Direct Injection \\
\hline BTDC & Before Top Dead Centre \\
\hline BP & Brake Power \\
\hline FC & Fuel Consumption \\
\hline SFC & Specific Fuel Consumption \\
\hline CV & Calorific Value \\
\hline
\end{tabular}

\section{REFERENCES}

Aziz, A., Rashid, A., Firmansyah, F., Shahzad, R. and Shahzad, R. (2010). Combustion analysis of a CNG direct injection spark ignition engine. International Journal of Automotive and Mechanical Engineering (IJAME), 2, 157-170. https://doi.org/10.15282/ijame.2.2010.5.0013

Bakar, R. A., Kadirgama, K., Sharma, K. V., Rahman, M. M. and Semin. (2012). Application of Natural Gas for Internal Combustion Engines. INTECH Open Access Publisher.

Hassan, M. K., Aris, I., Mahmod, S. and Sidek, R. (2010). Influence of injection and ignition of CNG fuelled direct injection engine at constant speed. Australian Journal of Basic and Applied Sciences, 4(10), 4870-79.

Jahirul, M. I., Masjuki, H. H., Saidur, R., Kalam, M. A., Jayed, M. H. and Wazed, M. A. (2010). Comparative engine performance and emission analysis of $\mathrm{CNG}$ and gasoline in a retrofitted car engine. Applied Thermal Engineering, 30(14), 2219-2226. https:/ / doi.org/10.1016/j.applthermaleng.2010.05.037

Kalam, M. A., Masjuki, H. H., Mahlia, T. M. I., Fuad, M. A., Halim, K., Ishak, A. and Shahrir, A. (2009). Experimental test of a new compressed natural gas engine with direct injection.

Kalam, M. A. and Masjuki, H. H. (2011). An experimental investigation of high performance natural gas engine with direct injection. Energy, 36(5), 3563-3571. https://doi.org/10.1016/j.energy.2011.03.066

Liu Y., Yeom, J. and Chung, S. (2013). A study of spray development and combustion propagation processes of spark-ignited direct injection (SIDI) compressed natural gas (CNG). Mathematical and computer modelling, 57(1), 228-244. https://doi.org/10.1016/j.mcm.2011.06.035

Munde Gopal, G. and Dalu Rajendra, S. (2012). Compressed natural gas as an alternative fuel for spark ignition engine: A review. 2, 92-96.

Patel, R. J. and Brahmbhatt, P. A technical review of performance of CNG direct injection in spark ignition engine.

Semin, R. A. B. (2008). A technical review of compressed natural gas as an alternative fuel for internal combustion engines. Am.J. Eng. Appl. Sci, 1(4), 302-311. https://doi.org/10.3844/ajeassp.2008.302.311

Zeng, K., Huang, Z., Liu, B., Liu, L., Jiang, D., Ren, Y. and Wang, J. (2006). Combustion characteristics of a direct-injection natural gas engine under various fuel injection timings. Applied thermal engineering, 26(8), 806-813. https://doi.org/10.1016/j.applthermaleng.2005.10.011 